\title{
A Simple and Swift Method for Isolating High Quality RNA from Jute (Corchorus spp.)
}

\section{Niaz Mahmood, Razib Ahmed, Muhammad Shafiul Azam and Haseena Khan*}

Department of Biochemistry and Molecular Biology, University of Dhaka, Bangladesh

Key words: Jute, Corchorus spp., Swift method, RNA isolation, RT-PCR

High quality RNA extraction is a prerequisite for various types of genetic analyses. Many a time, the existing RNA isolation methods and commercial kits are either time consuming or fail to isolate high quality RNA from plants rich in polysaccharides, oil and other secondary metabolites since different plants contain different amounts of nucleic acids (Khan et al. 2004, Loomis 1974). This problem is particularly acute in case of jute (Corchorus spp.), which is rich in mucilage and other polysaccharides that tends to interfere with the downstream processes (Kundu et al. 2011, Pandey et al. 1996). Several guanidium salt based methods have been successful for RNA isolation from jute seedlings (Khan et al. 2004), but are often cumbersome and expensive; hence limit simultaneous processing of large number of samples. Here we report a simplified and swift protocol for isolating high quality RNA from jute by making key modifications in tissue denaturation and precipitation steps in the protocol described by Ghawana et al. (2011). The protocol allows consistent production of high quality RNA from different species, which makes it particularly suitable for comparative plant genome research. The extraction time has been reduced from two days (for standard guanidium-acid-phenol extraction protocols) to about one hour and the extracted RNA was suitable for downstream processes like cDNA synthesis and expression pattern analysis.

Seeds of Corchorus capsularis (white jute) and C. olitorius (Tossa) were germinated on moist blot papers in Petri dishes at $25^{\circ} \mathrm{C}$, seedlings were collected after 3 days, frozen in liquid nitrogen and immediately stored at $-80^{\circ} \mathrm{C}$ until the time RNA was isolated (Mahmood et al. 2010).

*Author for correspondence. <haseena@univdhaka.edu, haseena@du.ac.bd>. 
About $0.5 \mathrm{~g}$ of sample tissue was pulverized to a fine powder in liquid nitrogen using pre-chilled RNase-free mortar and pestle. Then $3 \mathrm{ml}$ of denaturing solution containing $88 \%$ (v/v) DEPC-phenol saturated with Tris, $0.2 \%$ $(\mathrm{w} / \mathrm{v})$ sodium dodecyl sulphate (SDS), $4 \%(\mathrm{v} / \mathrm{v})$ of $1 \mathrm{M}$ sodium acetate and $8 \%$ $(\mathrm{v} / \mathrm{v})$ of 0.5 M EDTA ( $\mathrm{pH} 8.0)$ was added. The samples, which freeze after the addition of denaturing solution, are allowed to thaw at room temperature. Next $1 \mathrm{ml}$ of DEPC-treated water was added, mixed by grinding and allowed to stand for $5 \mathrm{~min}$. The sample was then divided into four aliquots and each of them was transferred to a $1.5 \mathrm{ml}$ RNase-free microcentrifuge tube and allowed to stand for another $5 \mathrm{~min}$. Then $0.3 \mathrm{ml}$ of chloroform was added to each tube; mixed well by inversion, vortexed briefly and incubated at room temperature for 5-10 min. The tubes were then centrifuged at $13,000 \mathrm{rpm}$ for $10 \mathrm{~min}$ at $4^{\circ} \mathrm{C}$ and the aqueous phase was transferred to a fresh microcentrifuge tube using a sterile transfer pipette. An equal volume of $10 \mathrm{M} \mathrm{LiCl}$ was added to each tube, mixed well by inversion, vortexed briefly and incubated at room temperature for $10 \mathrm{~min}$ to allow the nucleic acids to precipitate. After precipitation, the samples were centrifuged at 13,000 $\mathrm{rpm}$ for $10 \mathrm{~min}$ at $4^{\circ} \mathrm{C}$ and the supernatant was discarded. The pellet was then washed with $0.5 \mathrm{ml}$ of $70 \%$ ethanol and centrifuged at 13,000 rpm for $10 \mathrm{~min}$ at $4^{\circ} \mathrm{C}$. The supernatant was discarded and the tubes were kept inverted with their lids open on a stack of tissue papers in a laminar hood for 5$10 \mathrm{~min}$. Next the pellet was air-dried for 2 - $3 \mathrm{~min}$. The RNA pellet was then resuspended in $20 \mu \mathrm{l}$ of DEPC-treated water.

The quality and concentration of the RNA samples were checked using a spectrophotometer (NanoDrop, Technologies Inc.). The ratio of A260/280 was within 1.8 to 2.0 signifying high purity of RNA without any protein contamination (Table 1). Further, the ratio of $\mathrm{A}_{260 / 230}$ was greater than 1.8 indicating the absence of contamination proteins.

Table 1. RNA yield and quality detected with spectrophotometer.

\begin{tabular}{lccc}
\hline $\begin{array}{l}\text { Sample } \\
\text { species }\end{array}$ & $\mathrm{A}_{260 / 230}$ & $\mathrm{~A}_{260 / 280}$ & $\begin{array}{c}\text { RNA yield } \\
\text { (ng of RNA/g tissue) }\end{array}$ \\
\hline C. capsularis & 2.07 & 1.88 & 8507.50 \\
C. olitorius & 2.10 & 1.90 & 8246.75 \\
A. thaliana & 2.10 & 2.01 & 5273.75 \\
\hline
\end{tabular}

To validate the effectiveness of this protocol in other plant species, high quality RNA has also been isolated from the seedlings of model plant Arabidopsis thaliana in the same way as described above.

The integrity of total RNA was determined by distinct $28 \mathrm{~S}$ and $18 \mathrm{~S}$ rRNA bands after running the samples on a $1.2 \%$ denaturing formaldehyde-agarose gel 
(Fig. 1a). To confirm that the isolated RNA was amenable to downstream applications, reverse transcription-polymerase chain reaction (RT-PCR) was done. For RT-PCR, $3 \mu \mathrm{g}$ of poly $(\mathrm{A}+)$ RNA was reverse transcribed by SuperScript ${ }^{\mathrm{TM}}$ First-Strand Synthesis System of Invitrogen, USA, using a thermal cycler (Eppendorf Mastercycler Personal). Next normal PCR was carried out using the single stranded c-DNA with universal primers ( $\beta$-actin) and the resultant double stranded DNA was checked by agarose gel electrophoresis. The presence of bands of desired sizes validated the success of the protocol for downstream processes (Fig. 1b).

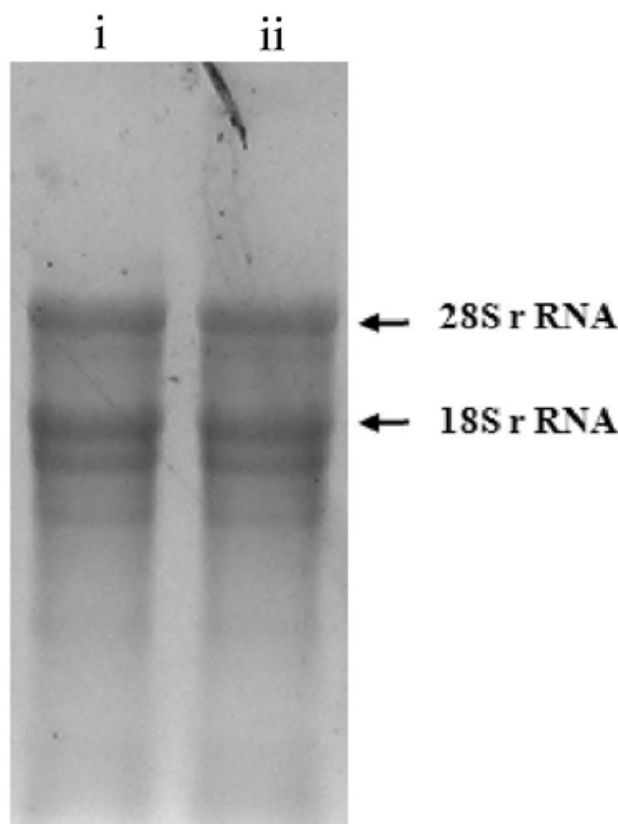

(a)

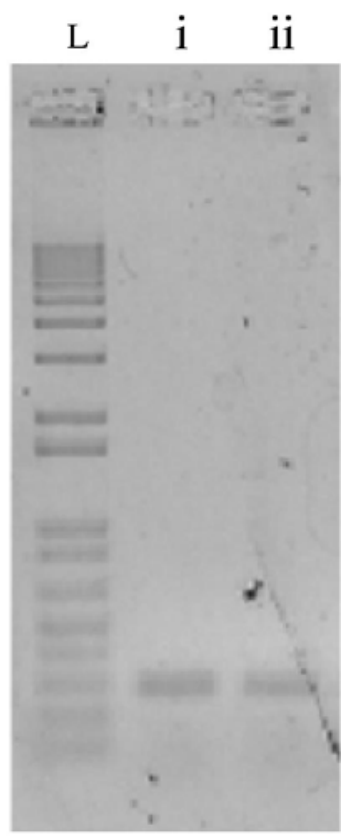

(b)

Fig 1. (a) RNA quality check using agarose gel electrophoresis, (b) bands of actin (288 bp) after RT-PCR. Here, $\mathrm{i}=$ Corchorus capsularis, $\mathrm{ii}=$ Corchorus olitorius and $\mathrm{L}=1 \mathrm{~Kb}$ ladder.

In Corchorus spp., the nucleic acids are most often found to be contaminated with protein, possibly due to the highly proteinaceous nature of mucilages (Kundu et al. 2011). Therefore in order to remove these proteins strong denaturants like phenol and SDS were used during this experiment. Maintenance of acidic $\mathrm{pH}$ is the critical factor to ensure the separation of RNA from DNA and proteins. Under acidic conditions, total RNA remains in the upper aqueous phase, while most of DNA and proteins remain either in the interphase or in the lower organic phase (Chomczynski and Sacchi 2006). So, the denaturing solution was composed of such reagents that could ensure the overall acidic condition of 
the reaction. During this study, RNA precipitation was done by $\mathrm{LiCl}$; as it does not efficiently precipitate DNA, protein or carbohydrate (Barlow et al. 1963, Cathala et al. 1983). It was thus used to remove these inhibitors of protein translation or cDNA synthesis.

Previously, Khan et al. (2004) reported another protocol for RNA isolation from jute seedlings. The distinguishing feature of the protocol described here is its simplicity, time and cost-effectiveness; which makes it suitable for simultaneous isolation of good quality RNA from a large number of samples as required for expression analyses (Fig. 2).

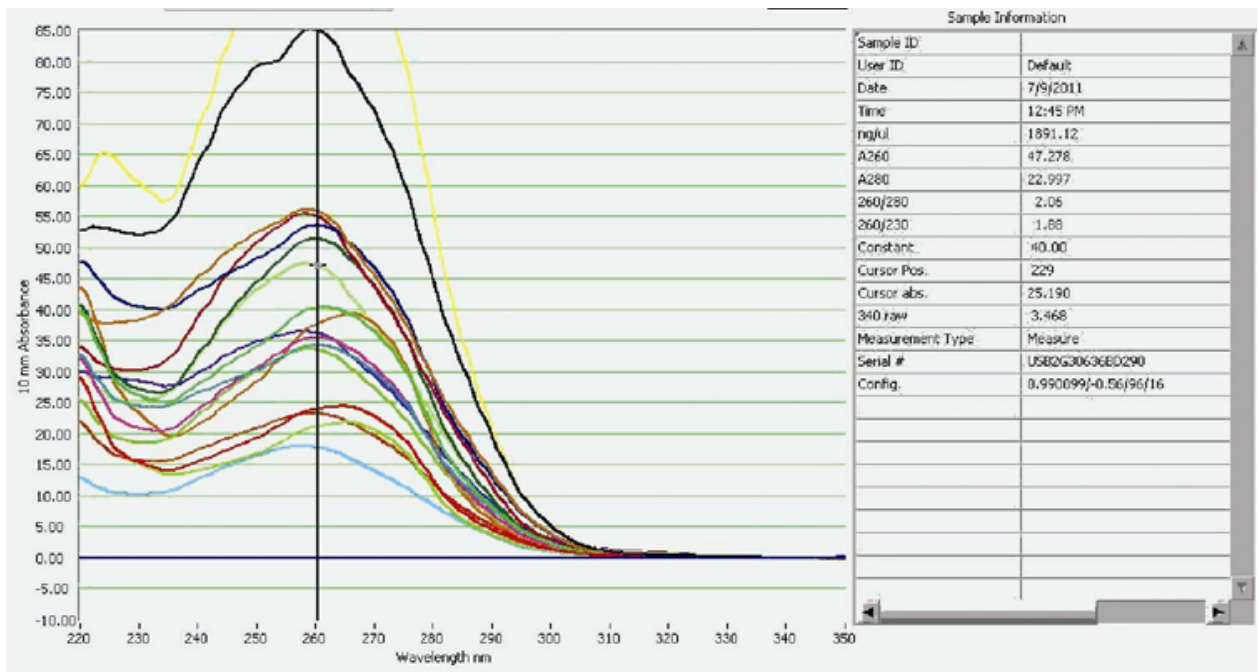

Fig. 2. Graph (produced by Nanodrop software) showing the highest peak at a range close to $260 \mathrm{~nm}$ wavelength indicating efficient isolation of high quality RNA from 17 different samples within a very short period of time.

It can be concluded that this modified protocol is highly effective for extracting good quality RNA from jute vis-à-vis other plant species.

\section{Acknowledgements}

This study was supported by the BAS-USDA. Authors are thankful to Dr. Jannat Zerin and Bangladesh Jute Research Institute (BJRI) for providing seeds of Arabidopsis and different species of jute.

\section{References}

Barlow J, Mathias A, Williamson R and Gammack D (1963) A simple method for the quantitative isolation of undegraded high molecular weight ribonucleic acid. Biochemical and Biophysical Research Communications 13: 61-66 
Cathala G, Savouret JF, Mendez B, West BL, Karin M, Martial JA and Baxter JD (1983) A method for isolation of intact, translationally active ribonucleic acid. DNA 2: 329-335.

Chomczynski P and Sacchi N (2006) The single-step method of RNA isolation by acid guanidinium thiocyanate-phenol-chloroform extraction: twenty-something years on. Nat. Protocols, 1: 581-585.

Ghawana S, Paul A, Kumar H, Kumar A, Singh H, Bhardwaj P, Rani A, Singh R, Raizada J and Singh K (2011) An RNA isolation system for plant tissues rich in secondary metabolites. BMC Research Notes 4: 85.

Khan F, Islam A and Sathasivan K (2004) A rapid method for high quality RNA isolation from Jute: Corchorus capsularis and C. olitorius L. Plant Tissue Cult. 14: 63-68.

Kundu A, Sarkar D, Bhattacharjee A, Topdar N, Sinha MK and Mahapatra BS (2011) A simple ethanol wash of the tissue homogenates recovers high-quality genomic DNA from Corchorus species characterized by highly acidic and proteinaceous mucilages. Electronic J. Biotech. 14: 10-11.

Loomis W. (1974) Overcoming problems of phenolics and quinones in the isolation of plant enzymes and organelles. Methods in Enzymology 31: 528-544.

Mahmood N, Azam MS, Islam MS, Sharmin S, Moosa MM, Hossain MA and Khan H (2010) Differentially expressed transcripts of wild and cultivated jute (Corchorus spp.) varieties upon fungal (Macrophomina phaseolina) infection. Annals of Biological Research 1: 120-127.

Pandey RN, Adams RP and Flournoy LE (1996) Inhibition of random amplified polymorphic DNAs (RAPDs) by plant polysaccharides. Plant Molecular Biology Reporter 14: 17-22. 